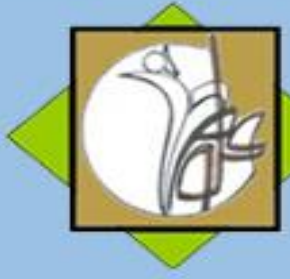

\author{
Research Article
}

\title{
The Relationship of Individuals' Attitude toward Advertising Through Sports with Their Beliefs: A Study of Football Spectators
}

\author{
Hossein Kordlu ${ }^{1}$, Alireza Elahi ${ }^{2}$, Abbas Khodayari $^{3}$
}

1. Hossein Kordlu, (Ph. D Student) University of Mohaghegh Ardabili , Ardabil, Iran.

2. Alireza Elahi, (Ph. D) Kharazmi University, Tehran, Iran.

3. Abbas Khodayari, (Ph. D) Islamic Azad University, Karaj Branch, Karaj, Iran.

\section{ARTICLE INFO}

Received December 2013

Accepted July 2014

\section{KEYWORDS:}

Beliefs, Attitude, Advertising Through Sport, Football Spectators

\section{CITE:}

Kordlu, Elahi, Khodayari, The Relationship of Individuals' Attitude toward Advertising Through Sports with Their Beliefs: A Study of Football Spectators, Research in Sport Management \& Motor Behavior, 2020: 10(20): 17-30

\section{ABSTRACT}

The purpose of this research is to predict the individual's attitude through their beliefs about advertising by using sports. This research is practical and is of the correlation method which was carried out as a field study. The statistical population was the spectators present at Azadi Stadium and according to the content of Cochran sample, 342 of the spectators were randomly chosen and filled in the questionnaire of advertising through sport called pyun (2006). The result of the regression analysis revealed that all the components of belief including the product information, social role and image, pleasure, annoying, good for economy, materialism and falsity had the capability of predicting the individual's attitude toward advertising through sport. The component good for economy had the most effect and materialism had the least effect on the individual's attitude toward advertising through sports. According these results, it is we essential pay attention to the quality and price of the predicts. On the other hand, we should use the advertising which are according to the culture of each in order to be more effective and attract the individual's attitude toward advertising through sports. 


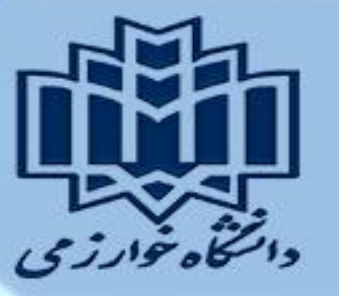

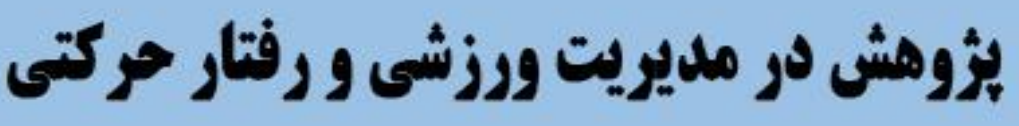

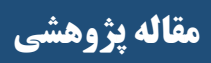

\section{ارتباط نكرش افر اد نسبت به تبليغات از طريق ورزش با باورهاى آنان: مطالعه تماشاكر ان فوتبال}

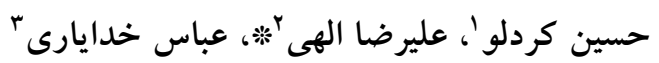

ا. دانشجوى دكترى مديريت ورزشى، دانشكده علوم تربيتى و روانشناسى، دانشكاه محقق اردبيلى، اردبيل، ايران.

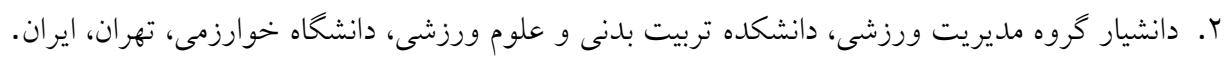

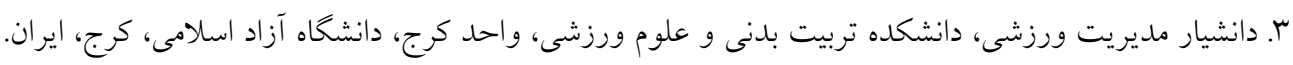

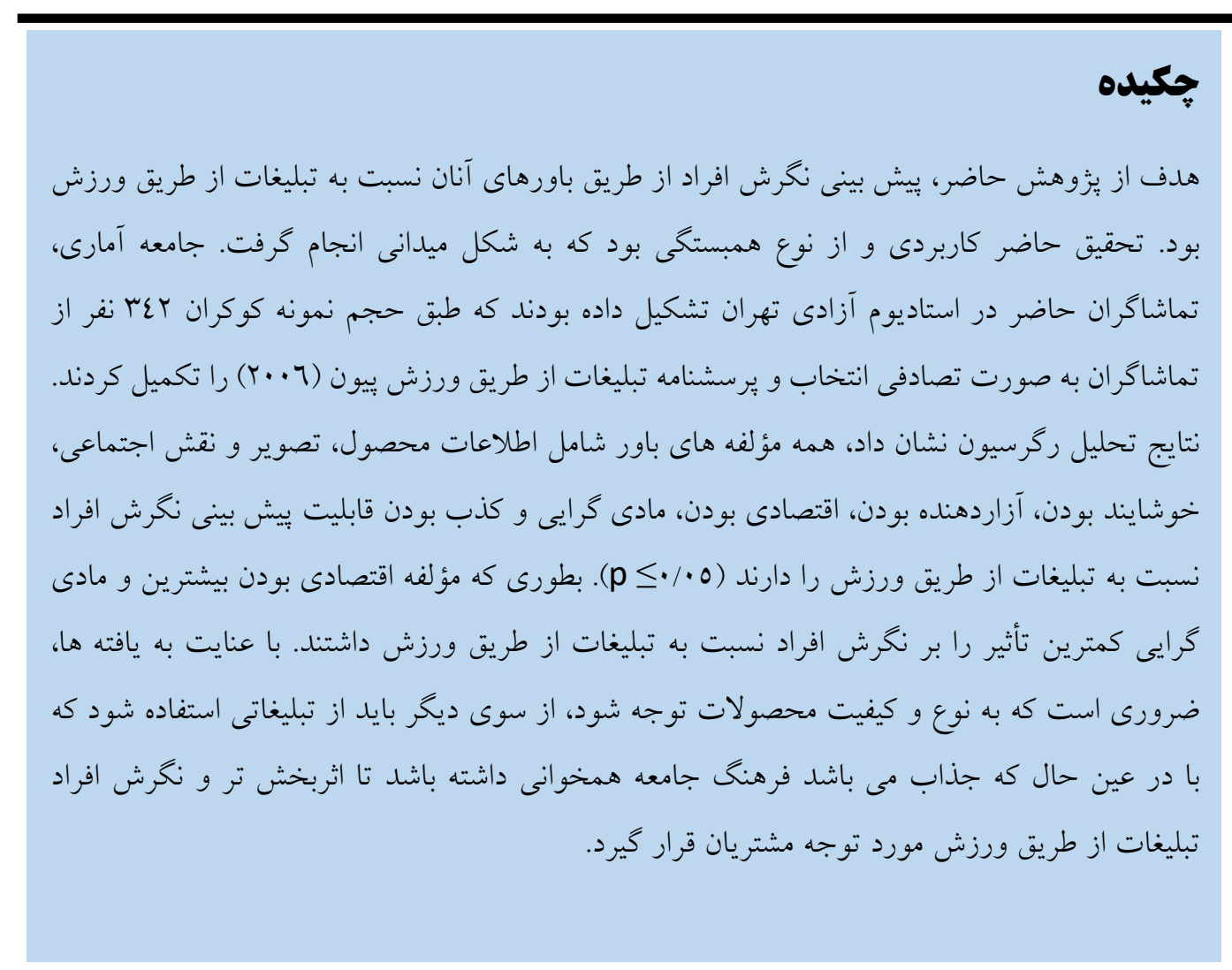

اطلاعات مقاله: دريافت مقاله دى اطلات مقاله

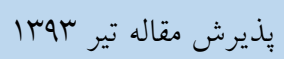

*ونويسنده مسئول:

alirezaelahi@yahoo.com

وازه هاى كليدى: باورها، نخرش، تبليغات از طريق وليق ورزش، تماشاكران فوتبال

ارجاع: - ال

كردلو، الهى، خدايارى. ارتباط نغرش ارش

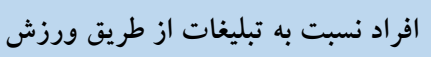
با باورهاى آنان: مطالعه تماشاكران فوتبال. يُزوهش در مديريت ورزشى باونى

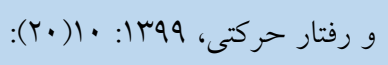
$\mid V-r$. 


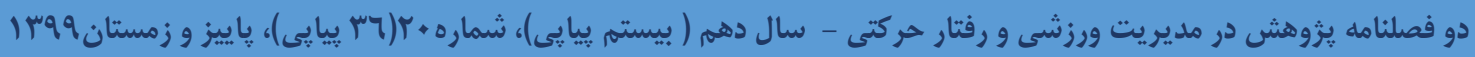

مقلهمه

دهلهاى اخير، بستر تحولات عميقى در اقتصاد جهانى بوده، تحولاتى كه نمود آن در اقتصادهاى ملى و منطقهاى بيش از بيش به جشم مى خورد. امروزه، در دورانى به سر مىبريم كه حلقه رقابت در صنعت تجارت، هر روز تنختر و بيّجيدهتر

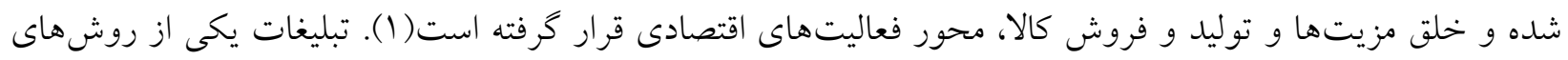
بازايابى است كه در انتقال اطلاعات (درباره كالا، خدمات و كسب و كار شركت) به مصرفكننده نفش مؤثرى دارد(Y). از اين رو، توليدكنند كان براى جلب رضايت مصرف كنندكان برنامهاى تبليغاتى مناسب را طراحى كرده و در معرض اجرا مى كذارند. بر همين اساس تبليغات به يك ابزار بسيار حياتى براى جلب توجه و جذب مخاطب تبديل شده است(r). شركتهاى تجارى معمولا براى معرفى كالاها و خدمات خود به دنبال بسترى خوب و مؤثر مىباشند، بسترى كه ورزش به عنوان يكى از مؤثرترين فضاهاى تبليغاتى آن را اختيار شركتهاى تجارى جهت معرفى كالا و خدمات قرار داده است.

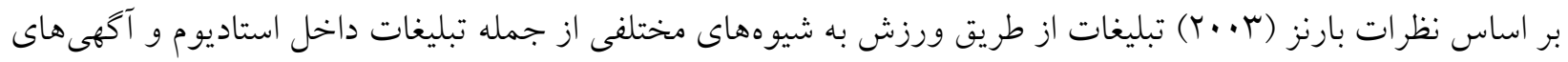

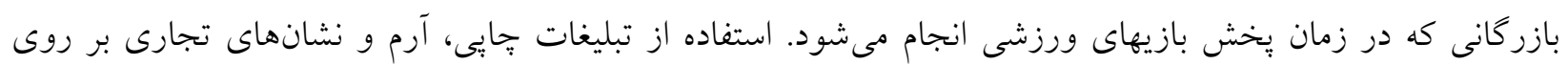
لباس، تجهيزات ورزشى و تبليغات مجازى در زمانى كه رويدادهاى ورزشى از تلويزيون يخش مىشوند نيز از ديخر

$$
\text { شيوههاى تبليغات از طريق ورزش محسوب مى شود(ع). }
$$

استفاده از تبليغات در حوزه ورزش بويزه فوتبال و استقبال كستردهاى كه افراد از آن مى كنند، بستر مناسبى براى تبليغات

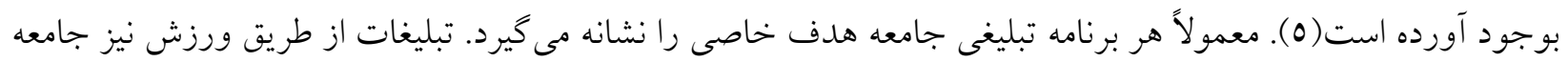
هدف خاص خود را دارد. در اين ميان تماشاكران (جه حاضر در استاديوم و خهه تماشاگران خانگى) به عنوان يك جامعه هدف عمده در تبليغات از طريق ورزش مطرح هستند. از اين رو، ارزيابى نخرش اين افراد نسبت به تبليغات از طريق ورزش بسيار اهميت دارد؛ جرا كه ثابت شده است اين نخرش نسبت به تبليغات است كه بر قصد و تمايل خريد مشتريان تأثير مى كذارد.

در مطالعات كذشته وازه باور 'و نخرش 'اغلب به عنوان يك مفهوم واحد استفاده شده است(7). اما در حال حاضر بين باور و نخرش تفاوت قائل شدهاند(V). به طورى كه فازيو (Y.V. باورها را به عنوان فرضيه هايى درباره ماهيت موضوعات

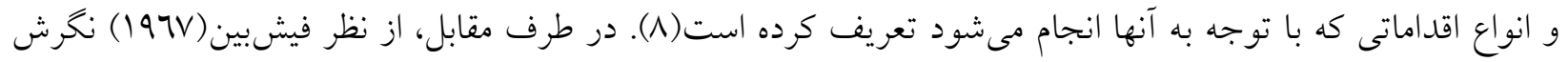
همان دوست داشتن و دوست نداشتنها است. يعنى مطلوب يا نامطلوب ارزيابى كردن اشيا، افراد و موقعيتها(9). از نظر وى سه جزء اصلى نخرش عبارتند از: ا. جزء شناختى (باورهاى يك فرد) ז. جزء عاطفى (احساسات فرد) س. جزء رفتارى (واكنش ها و يُاسخ هاى رفتارى افراد). جزء شناختى نخرش شامل باورهاى مصرف كننده در مورد كالا يا خدمات مىباشد. واكنش هاى احساسى به يك موضوع (كالا/ خدمت) نمايانخر جزء عاطفى يك نخرش است. جزء رفتارى نخرش عبارت

1- Belief

2- Attitude

https://jrsm.khu.ac.ir/ 


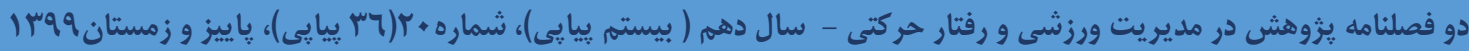

از تمايل فرد به واكنش به شيوهاى خاص به محصول يا يك فعاليت است. بيون و جيمز (1) (1) معتقدند، نخرشها هميشه

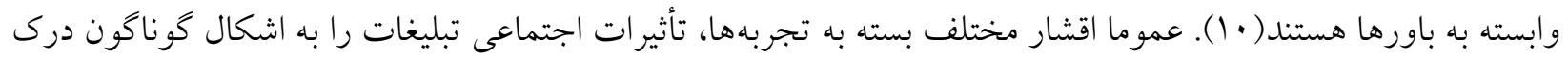
مى كنند. به طورى كه ممكن است افراد باور يكسانى نسبت به يكى موضوع داشته باشند، اما نخرش آنها نسبت به آن موضوع متفاوت باشد. به طور كلى مى توان كفت نخرش نسبت به تبليغات به عنوان، ذهنيت شكل گرفته شده براى بِاسخ مطلوب يا نامطلوب به تبليغات تعريف شده است( (1).

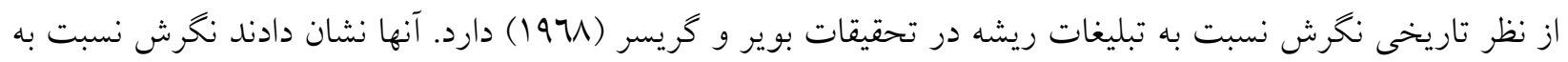

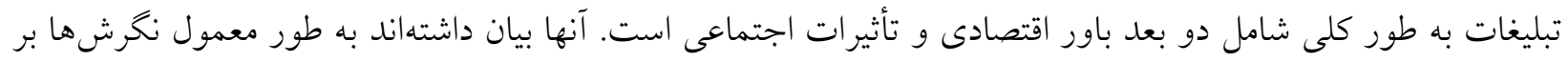

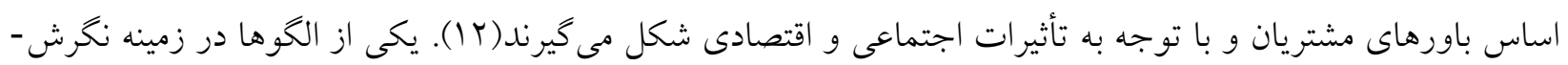

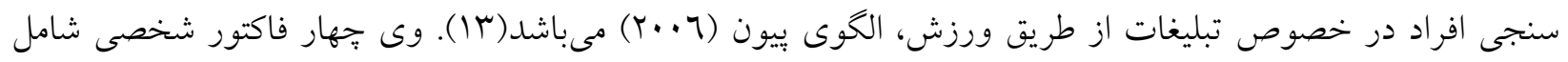
(اطلاعات محصول، تصوير و نقش اجتماعى، خوشايند يا لذتبخش بودن و رنجش يا آزردگى) و سه عامل اقتصادى و اجتماعى شامل (اقتصادى بودن، مادى گرايى و نامفهوم يا كذب بودن) و ارتباط آن با نخرش كلى نسبت به تبليغات از طريق ورزش را معرفى كرده است. جدول ا تعاريف هر يك از مؤلفهاى باور نسبت به تبليغات از طريق ورزش را نشان

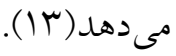

جدول ا: مؤلفههاى باور نسبت به تبليغات از طريق ورزش (rا (I)

\begin{tabular}{|c|c|c|}
\hline تعريف & 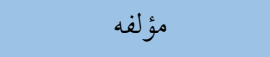 & مؤلفههاى باور \\
\hline نحوه انتقال اطلاعات درباره محصول مورد تبليغ به مشتريان از طريق ورزش را نشان مىدهد. & اطلاعات محصول & \multirow{4}{*}{ 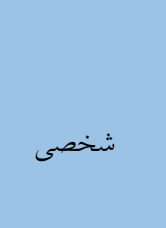 } \\
\hline تبليغات تا جه حد بيانخر نحوه نشان دادن تصوير يك محصول يا خدمات جديد به مشتريان مىباشد. & تصوير و نقش اجتماعى & \\
\hline با تبليغات از طريق ورزش تا جهه اندازه در افراد احساس خوشى و لذت ايجاد مىشود. & خوشايند بودن & \\
\hline تبليغات از طريق ورزش تا جه اندازه باعث احساس رنجش و آزردگى افراد مىشود. & رنجش و آزاردهنده بودن & \\
\hline و تبليغات از طريق ورزش جِخونه باعث رقابت بين رقبا و كاهش قيمتها و افز ايش كيفيت محصولات & اقتصادى بودن & \multirow{3}{*}{ اقتصادى و } \\
\hline تبليغات از طبه آن ندارند. ورزش تا جهه اندازه باعث مىشود افراد محصولات و خدماتى را تهيه نمايند كه & مادى كرايى & \\
\hline اطلاعاتى كه تبليغات از طريق ورزش به مشتريان ارائه مى دهد تا جِه اندازه كذب و نامفهوم است. & نامفهوم و كذب بودن & \\
\hline
\end{tabular}

تبليغات با كذشت زمان در بين مردم منفى تر شده است. اين موضوع را بيشتر در رسانهاى تبليغاتى مىتوان مشاهده نمود كه مدت زمان طولانى است كه اقدام به تبليغ محصولات و خدمات مختلف مى ممايند. از رسانههايى كه در نزد افراد داراى نكرش منفى شده است، تلويزيون مى باشد. طى تحقيقى كه جيتيتاورن و همكارانش (1) (1) انجام دادند به اين نتيجه رسيدند، به طور كلى افراد نخرش منفى نسبت به تبليغات تلويزيونى ييدا كردهاند. مشتريان اكر تبليغاتى كه مشاهده نمايند

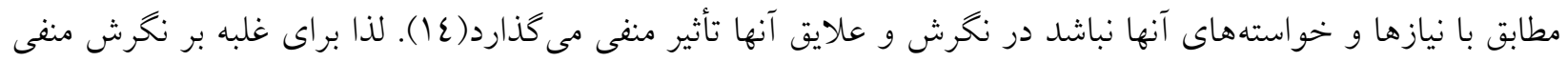




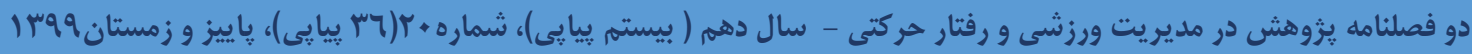

افراد به تبليغات بر محتواى بيامها تأكيد داشتند. تحقيق مراتويج، جليكا و بويويج (ع) (ب) كه مطابق با موضوع فوق بود نشان داد نخرش مصرف كنند گان نسبت به تبليغات از طريق ورزش مثبت ازت از نحرش آنها به تبليغات عام بود، در حالى كه همه مؤلفهاى باور به جز مادى گرايى، تأثير قابل توجهى بر نخرش مصرف كنند گان نسبت به تبليغات از طريق ورزش در مونته نخرو داشتند. تبليغات از طريق ورزش براى تبليغ بازاريابى كه ابزار تبليغاتى بسيار جذاب ترى در سراسر جهان است مى تواند از آن براى تقويت ارتباط با مصرف كنند كان و ترغيب آنها براى خريد محصولات يا خدمات خاص استفاده كند(10). از سوى ديخر شكارى، موسوى و غلامى (·.Y.) طى تحقيقى نشان دادند كه عوامل موثر بر نخرش مشتريان نسبت به تبليغات شامل هفت شاخص درآمدزايى، قانونى سازى، آكاهى اجتماعى، خانو اده و دوستان، صاحبان تبليغات، نظارت و كيفيت تبليغات معرفى كردند. در بايان خاطر نشان كردند كه براى داشتن تبليغات اثربخش مىتوان به عناصرى

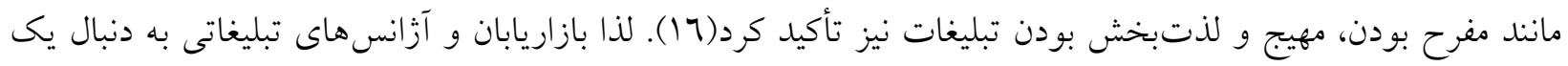
بستر تبليغاتى بودند كه بتوانند تبليغات را مفرح، مهيج و خوشايند ارائه نمايند. با توجه به اين فاكتورها، ورزش به عنوان بسترى مناسب براى ايجاد تغيير در نخرش منفى افراد نسبت به تبليغات بركزيده شد. در اين زمينه كشميرى، الهى و اكبرى يزدى (197 (1) در مطالعه خود به اين نتيجه رسيدند، تبليغات زمانى موفقتر خواهد بود كه تبليغ كنندكان درك بهترى از آنجهه بر نخرش مشتريان تأثير مى گذارد، داشته باشند. آنها همجنين دريافتند در عصرى كه رقابت شديدى براى جلب توجه

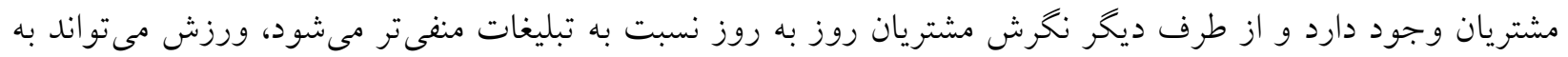
عنوان يك صحنه تبليغاتى منحصربه فرد نكرش مشتريان نسبت به تبليغات را تقويت نمايد(•(1). همجنين بيون، كيون،

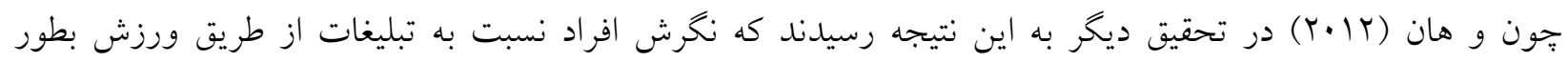
معنى دارى مثبت تر از نخرش نسبت به تبليغات عمومى، تلويزيونى و همجنين تبليغات آنلاين مىباشد(IV). همانطور كه اشاره شد سازمانها و شركتها از روش هاى مختلفى براى شناساندن و معرفى محصولات و كالاهاى توليدى خود استفاده مى كنند. لذا مى توان برداشت كرد كه در حال حاضر تبليغات از طريق ورزش به دليل استقبال كسترده افراد از ورزش،

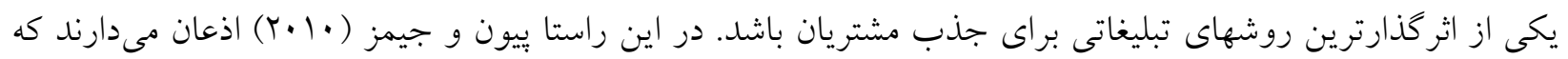
تبليغات از طريق ورزش مىتواند نخرش مثبتى در مشتريان بوجود آورد كه در نهايت باعث رفتار خريد محصول شود( (1). در همين زمينه يويويج (19 (Y) نشان داد كه نكرش مصرف كنند كان نسبت به تبليغات از طريق ورزش به طور كلى مثبت تر از تبليغات است، در حالى كه برخى از باورها (نقش و تصوير اجتماعى، لذت جويى و كذب بودن) به طور قابل

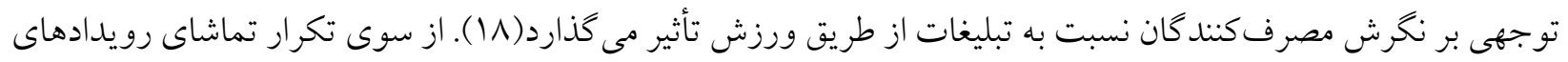
ورزشى نيز بر نكرش مصرف كنندگان تاثير گذار است به طورى كه تماشاكرانى كه رويدادهاى ورزشى رو بيشتر دنبال

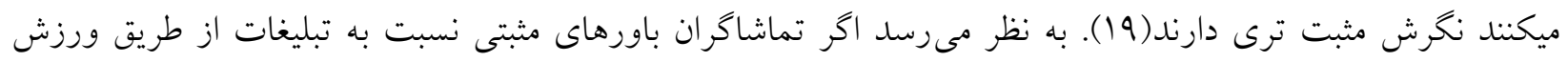
داشته باشند، نخرش آنها نسبت به تبليغات بهتر و نهايتاً تمايل به خريد و رفتار خريد آنها افزايش خواهد يافت. در همين خصوص بهنام و طوسى (rM I) بيان مى كنند كه با ايجاد نخرش مثبت در افراد نسبت به تبليغات مىتوان بر قصد 


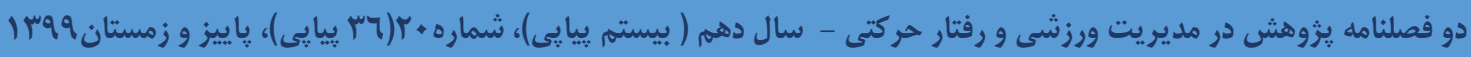

مصرف كننده در آينده نيز تأثير كذاشت(·Y). اين موضوع اتفاق خوشايندى براى شركتها و سازمانهايى خواهد بود كه از طريق ورزش اقدام به تبليغ كالاها و خدمات خود مى كنند. در اين ميان اخر مشخص شود كداميك از مؤلفهاى باور بهتر مى تواند نكرش تماشاكران را بيشبينى نمايد، مىتوان با اولويتبندى مناسبى به باز اريابان و تبليغ كنندكان ارائه نمود. نحاهى به مطالعات در حوزه بازاريابى ورزشى مبين اين مطلب است كه مطالعات اندكى در داخل كشور در زمينه تبليغات بويزه تبليغات از طريق ورزش انجام شده است. مطالعه در زمينه نخرش افراد نسبت به تبليغات مىتواند بسيار سودمند باشد جر ا كه از مهمترين بيشبينها براى خريد كالاها و خدمات، نخرش مثبى است كه توسط تبليغ محصولات و خدمات در ذهن مشتريان ايجاد مى شود. لذا يزوهشخران اين مطالعه به دنبال ياسخ گويى به دو سؤال اساسى زير هستند:

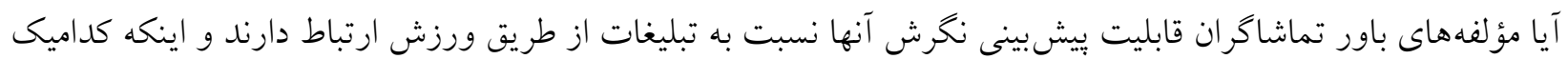
از مؤلفهاى باور يِيشبين قوىترى براى نخرش نسبت به تبليغات از طريق ورزش هستند؟

\section{روششناسى}

يزوهش حاضر كاربردى و از نوع همبستكى است. در اين تحقيق نحرش افراد نسبت به تبليغات از طريق ورزش توسط باورهاى آنها مورد بررسى قرار گرفت. جامعه آمارى تحقيق، تماشاكران حاضر در استاديوم آزادى تهران تشكيل مىدادند كه براى ديدن بازيهاى ليگ برتر فوتبال به استاديوم آمده بودند. با توجه به اين كه تبليغات در استاديوم آزادى نسبت به به بهرئ ساير استاديومها حرفهاىتر انجام مى شودو از سوى ديخر اكثر مسابقات اين استاديوم به صورت مستقيم در تلويزيون نيز نمايش داده مىشود. لذا تماشاكران اين استاديوم به عنوان جامعه آمارى تحقيق انتخاب شدند. بنابراين تبليغات موجود در استاديوم آزادى تهران هم براى تماشاكران حاضر در استاديوم و هم براى تماشاكران خانكى قابل مشاهدهتر است. با توجه به نامشخص بودن تعداد دقيق جامعه آمارى، از فرمول حجم نمونه كوكران براى جوامع بزرگ و نامشخص استفاده شد.

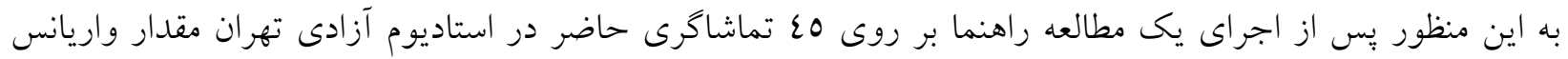

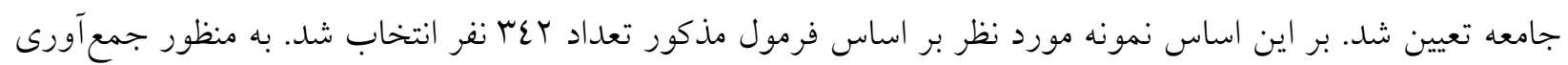
دادههاى مورد نياز از فرم اطلاعات فردى براى جمع آورى اطلاعات جمعيتشناختى تماشاكران استفاده شد.

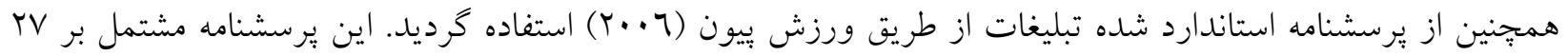
سؤال است كه هفت مؤلفه باور را در بر مى گيرد. جهار مؤلفه شخصى شامل اطلاعات محصول (0 سؤال)، تصوير و نقش (ه الش اجتماعى (0 سؤال)، خوشايند يا لذتبخش بودن (ب سؤال) و رنجش يا آزاردهنده بودن (r سؤال) و سه مؤلفه اقتصادى بوس و اجتماعى شامل اقتصادى بودن (ع سؤال)، مادى گرايى (ع سؤال) و نامفهوم يا كذب بودن (r سؤال) و همجنين ارتباط

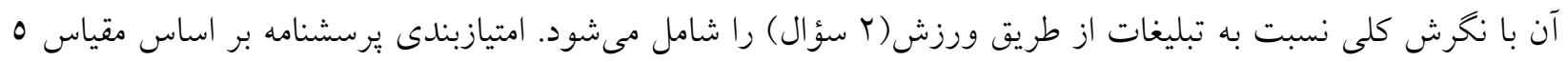
ارزشى ليكرت (از كاملا مخالف=ا تا كاملا موافق=0) است. لازم به ذكر است اصل نسخه يرسشنامه تبليغات از طريق

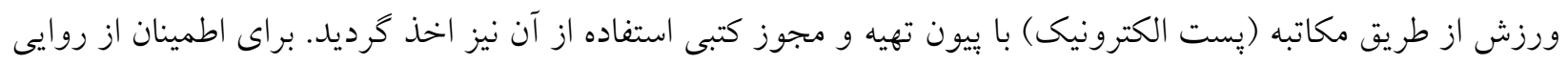




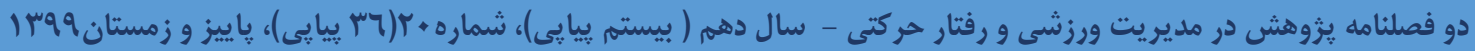

صورى و محتو ايى سؤالات پِ از اجراى فرايند سه مرحلهاى ترجمه، از نظرات متخصصين و بازاريابان ورزشى استفاده

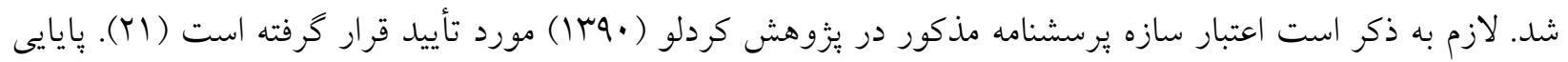

$$
\text { ابزار اندازه گيرى 10/ • مورد تأييد قرار خرفت. }
$$

به منظور تجزيه و تحليل دادهها از روش هاى آمارى توصيفى (ميانخين، انحراف معيار و جداول نمودارها) و براى نرمال بودن توزيع دادها از آزمون كالموكروف اسميرنف باستفاده شد. نتايج نشان داد، دادها از توزيع نرمال برخوردارند. همجنين به منظور بيشبينى متغير ملاك (نخرش نسبت به تبليغات از طريق ورزش) توسط متغيرهاى بيشبين (مؤلفههاى باور) از روش رگرسيون جند گانه از نوع Enter استفاده شد.

\section{يافتهاى تحقيق}

ارائه يافتهاى تحقيق در دو بخش توصيفى و استنباطى صورت گرفته است. در بخش نتايج توصيفى دادهها، همانطور كه

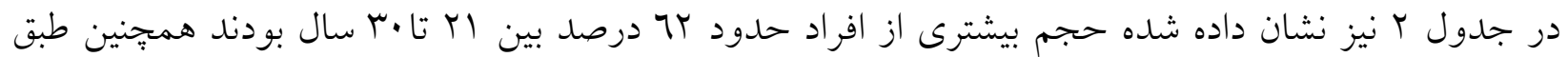
اطلاعات جدول r حدود OV درصد از افراد داراى تحصيلات دانشخاهى مىباشند و با توجه به اطلاعات موجود حدود •ع درصد افراد دانشجو هستند.

جدول Y: مشخصات فردى جامعه تحت بررسى

\begin{tabular}{|c|c|c|c|c|c|c|c|c|}
\hline \multicolumn{3}{|c|}{ شغل } & \multicolumn{3}{|c|}{ تحصيلات } & \multicolumn{3}{|c|}{ سن } \\
\hline $\mathbf{N}$ & درصد & نوع & $\mathbf{N}$ & درصد & نوع & $\mathbf{N}$ & درصد & دامنه \\
\hline 07 & $17 / \varepsilon$ & كارمند & $1 \varepsilon$ & $\varepsilon / 1$ & زير دييلم & 77 & $19 / r$ & زير ·r سال \\
\hline YY & $V / 7$ & كارگر & ir. & r^ & دييلم & YIE & $7 Y / Y$ & اب تا •r سال \\
\hline IrV & $\varepsilon \cdot / 1$ & دانشجو & ro & $1 \cdot / r$ & ديِلمفوق & $\varepsilon$. & $11 / \mathrm{V}$ & اب تا•ع سال \\
\hline 1I & $r r / V$ & آزاد & $10 \varepsilon$ & «o & ليسانس & rr & $7 / \varepsilon$ & بالاى اع سال \\
\hline ir & $r / 0$ & بيكار & 9 & $r / 7$ & بالاتر از ليسانس & & & \\
\hline 11 & $0 / r$ & نظامى & & & & & & \\
\hline ir & $r / 0$ & ساير & & & & & & \\
\hline
\end{tabular}

در بخش آمار استنباطى، نتايج مطالعه نشان داد، بين همه مؤلفههاى باور و نخرش نسبت به تبليغات از طريق ورزش رابطه معنادارى وجود دارد. به طورى كه جهار مؤلفه اقتصادى بودن (r=/27)، اطلاعات محصول (r=/ro/r)، تصوير و نقش اجتماعى (r=/r/r)، خوشايند و لذتبخش بودن (r=/r/r) رابطه مثبت و معنادارى با نخرش نسبت به تبليغات از طريق

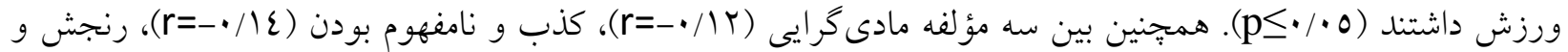

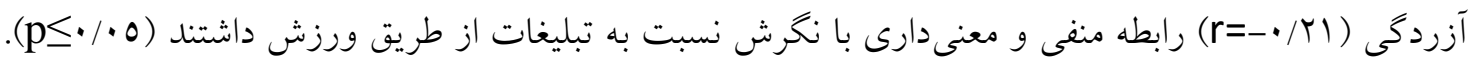

\section{Kolmogorov-Smirnov}

https://jrsm.khu.ac.ir/ 


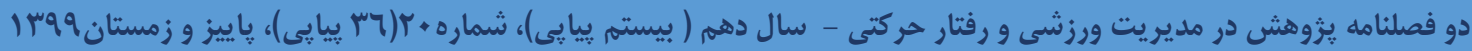

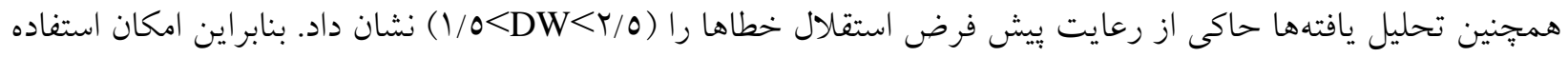
از روش رگرسيون وجود داشت. جدول r مشخصكنندهاى كلى تحليل رگرسيون اجرا شده را نشان مىدهد. همانخونه كه ملاحظه مىشود مؤلفهاى باور در مجموع قابليت بيشبينى .7 درصد از متغير نخرش نسبت به تبليغات از طريق ورزش را داشتند.

جدول ץ: تحليل رگرسيونى متغيرهاى ييشبين (مؤلفهاى باورهاى تماشاكران) بر نخرش به تبليغات از طريق ورزش

\begin{tabular}{|c|c|c|c|c|c|c|}
\hline سطح معنادارى & $\mathrm{F}$ & Durbin Watson & تعديل شده R R & $\mathrm{R}^{r}$ & $\mathrm{R}$ & مدل \\
\hline.$/ \cdot \cdot 1$ & Iro/rA & $r / .0$ & $\cdot / 7$. & $\cdot / 7 r$ & $\cdot / \mathrm{V} q$ & 1 \\
\hline
\end{tabular}

به منظور تعيين تأثير مؤلفههاى باور(متغير بيشبين) بر نخرش افراد نسبت به تبليغات از طريق ورزش (متغير ملاك) از

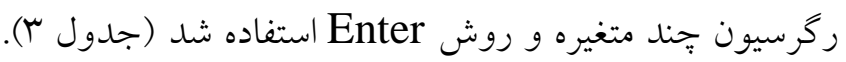

جدول rا: مشخص كنندهاى آمارى، ميزان و جهت تأثير هر يك از متغيرهاى بيش بين بر نخرش نسبت به تبليغات از طريق ورزش

\begin{tabular}{|c|c|c|c|c|c|}
\hline سطح معنى دارى & $\mathrm{t}$ & بتاى استاندارد شده & خطاى استاندارد & ضرايب ركرسيون & مدل \\
\hline$\bullet \cdot \cdots 1$ & $7 / 7 \varepsilon$ & - & $\cdot / 77$ & $\varepsilon / \Gamma V$ & عدد ثابت \\
\hline.$/ 11$ & y/or & $\cdot . / r 0$ & $.1 \cdot 0$ & $\cdot / r Y$ & اطلاعات محصول (A) \\
\hline$\% \cdot \cdot 1$ & $9 / Y)$ & $\cdot / \varepsilon 7$ & $\cdot / \cdot \varepsilon$ & $\cdot / 40$ & (B) اقتصادى بودن \\
\hline$\cdot 1 \cdot+1$ & $V / r q$ & $\cdot /$ / & $\cdot / \cdot \varepsilon$ & $\cdot / r r$ & (C) خوشايند بودن \\
\hline$\cdot / r \varepsilon$ & $-r / l r$ & $-\cdot / 1 \varepsilon$ & $\cdot / \cdot \varepsilon$ & $-\cdot / M r$ & (D) \\
\hline$\cdot / \cdot r \mid$ & $-r / 9 \Lambda$ & $-\cdot / Y \mid$ & $\cdot 1 \cdot 0$ & $-\cdot / r \mid$ & آزاردهنده بودن (E) \\
\hline $.1 \cdot 10$ & $0 / \cdot$ & $\cdot / T Y$ &.$/ \cdot r$ &.$/ 17$ & تصوير نقش اجتماعى(F) \\
\hline$\cdot / \cdot \varepsilon \varepsilon$ & $-Y / Z \Lambda$ & $-\bullet / M r$ &.$/ .0$ & $-\cdot / 1 \varepsilon$ & مادى گرايى \\
\hline
\end{tabular}

نتايج نشان داد همه مؤلفههاى باور بيشبين معنادارى براى نخرش نسبت به تبليغات از طريق ورزش هستند. در اين ميان

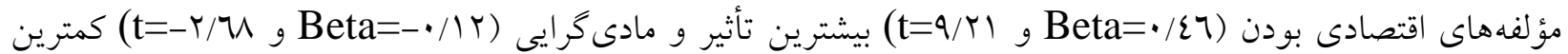

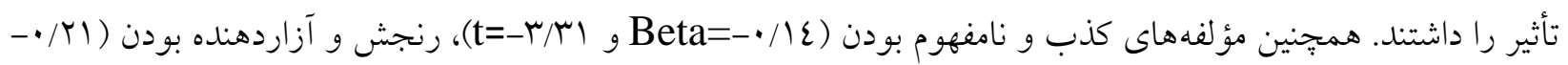
و Beta= از طريق ورزش داشتهاند. بر اساس يافتهاى بدست آمده معادله حاصل از تحليل ركرسيون به صورت زير قابل تبيين 


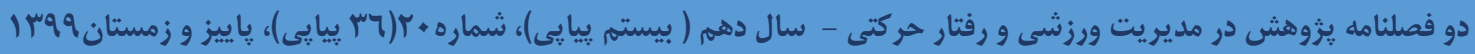

(•) نكرش نسبت به تبليغات از طريق ورزش همجنين شكل ا بيانخر ضرايب بتاى مؤلفهاى باور بر روى نخرش نسبت به تبليغات از طريق ورزش است

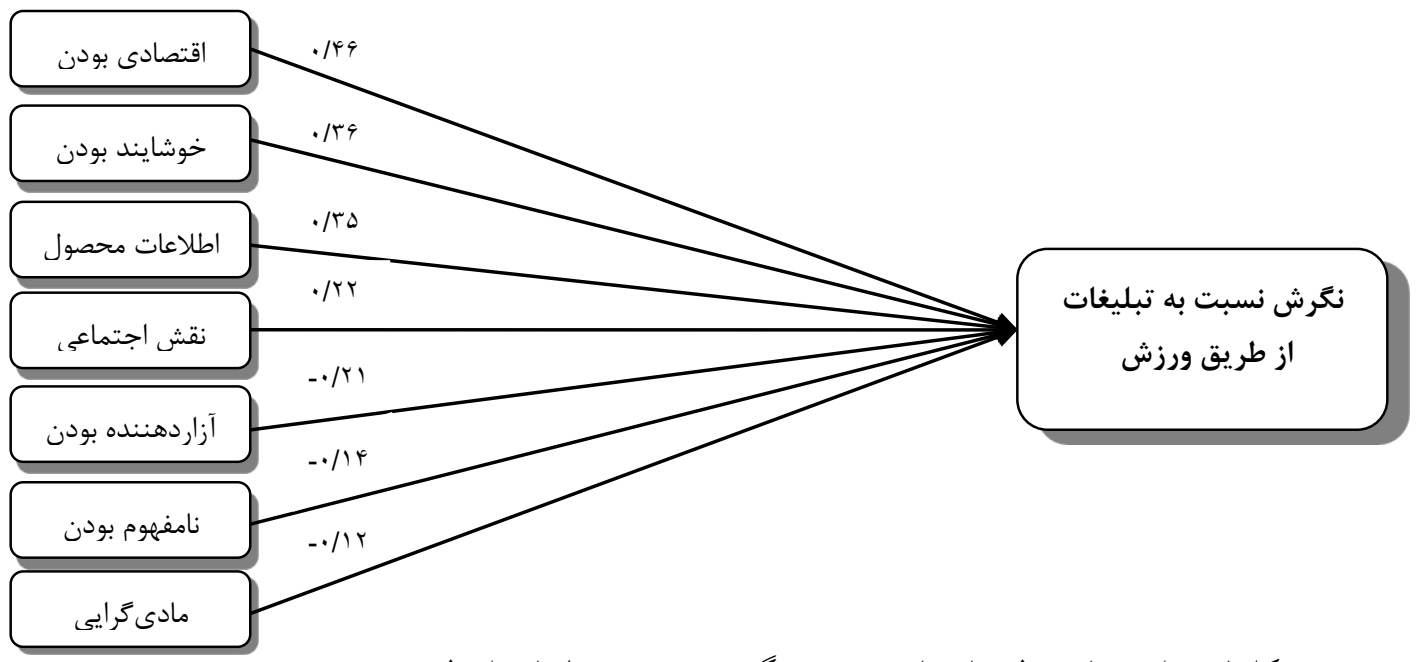

شكل ا: ضرايب بتاى مؤلفهاى باور بر روى نكرش نسبت به تبليغات از طريق ورزش

بحث و نتيجه تيرى: تبليغات تجارى، يك نيروى فزاينده در معرفى كالاهاى جديد به شمار مى آيد. تبليغات بازويى نيرومند براى ارتقاء هويت،

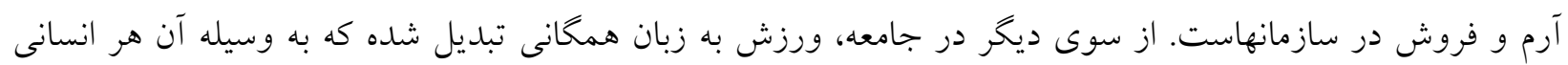
مى تواند خود را به اجتماع بيوند زده و ارزشهاى خود را مطرح كند. از اين رو ورزش يكى از مؤثرترين فضاهاى تبليغاتى را در دسترس صاحبان كالا و خدمات قرار داده است. از طرفى همه كير شدن ورزش و استقبال گستردهاى كه از ورزش صورت مى گيرد باعث شده تا سازمانها و شركتها از طريق ورزش، كالاها و محصولات خود را تبليغ كنند. يافتهاى تحقيق نشان داد تمامى مؤلفههاى باور بيشبين معنى دارى براى نخرش افراد نسبت به تبليغات از طريق ورزش مىباشند. در مجموع اين مؤلفهها •7 درصد از واريانس متغير ملاك را تبيين كردند. از بين اين مؤلفهها، اقتصادى بودن و خوشايند بودن بيشترين ميزان تأثير را بر نخرش افراد داشتند. در حالى كه كمترين ميزان تأثير نيز مربوط به مؤلفه مادى كر ايى ميى بود. اولويتهاى بدست آمده به خوبى نشان مىدهد كه بازاريابان و آزانسهاى تبليغاتى به منظور ايجاد نخرش مثبت در

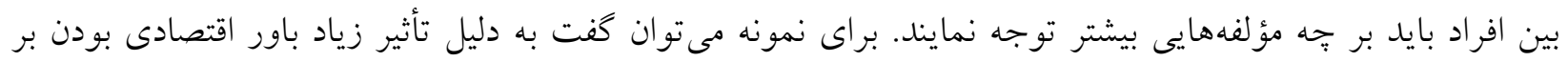
نخرش افراد، بازاريابان و آزانسهاى تبليغاتى بايد بر اصل اقتصادى بودن محصولات و خدماتى كه از طريق ورزش تبليغ مىشود، توجه داشته باشند. همانطور كه يويويج (Y.19) بيان مىدارد، باور اقتصادى بودن نخرش مثبتى را در مشتريان

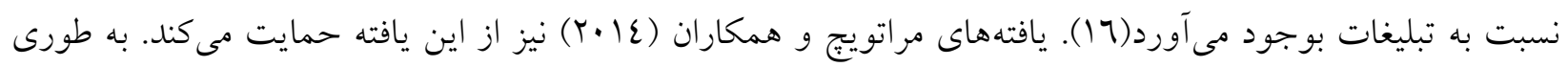




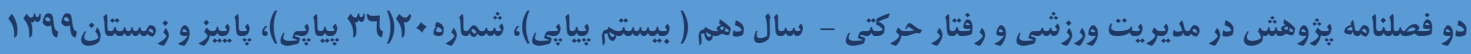

كه مراتويج و همكاران (عا ·r) كزارش دادند كه ارتباط مثبتى بين باور اقتصادى بودن تبليغات و نخرش نسبت به تبليغات وجود دارد(10). در اين ميان با عنايت به اينكه ساير مؤلفههاى باور بيشبين معنادارى براى نخرش نسبت به تبليغات از طريق ورزش هستند، آزانسها و بازاريابان نبايد از مؤلفهاى ديكر غافل شوند. نكته قابل ذكر ديخر اينكه در جوامع مختلف ممكن است مشتريان باورهاى متفاوتى از تبليغات، بويزه تبليغات از طريق ورزش داشته باشند. يا حتى در جامعه

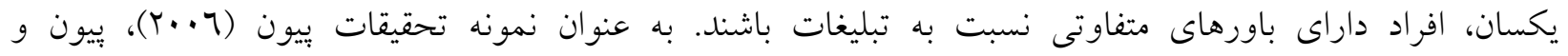

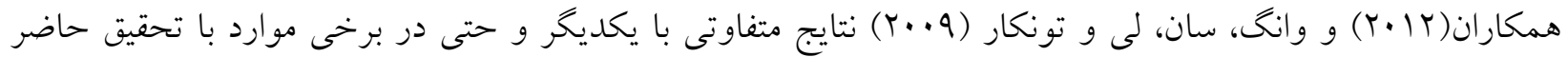
نشان دادند. بيون (T + ㄱ) مؤلفه اطلاعات محصول را به عنوان تأثير كذارترين مؤلفه باور نسبت به تبليغات كزارش كرده

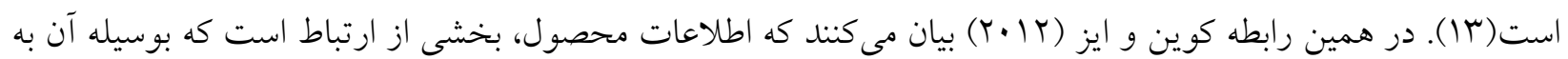
ارزشها، اهداف و انتظارات مشتريان معنا و مفهوم مىبخشد. از سوى ديخر تبليغات نقش حياتى در آماده كردن اطلاعات در رابطه با محصولات توليدى دارد(Y) در همين رابطه بيون و همكاران (Y. (Y) اطلاعات محصول و خوشايند بودن را دو مؤلفه تأثير كذار بر نخرش افراد نسبت به تبليغات از طريق ورزش معرفى كرده است(IV). در حالى كه وانخ و همكاران

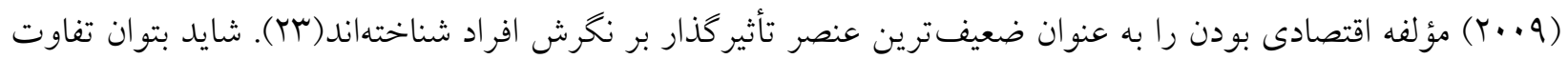
در نتايج مذكور را در فرهنگ و قلمرو متفاوت آنها جستجو كرد. از سوى ديخر هر دو تحقيق مذكور دانشجويان را به عنوان قلمرو تحقيق در نظر گرفته بودند در حالى كه تحقيق حاضر تماشاگران را به عنوان نمونه مورد بررسى قرار داد. تفاوت در نتايج فوق با تحقيق حاضر را نيز مىتوان به انخيزه جامعه مورد مطالعه نيز مربوط دانست. به طورى كه ماسانويج (Y.11) بيان مى كند كه ورزش مىتواند بر اساس انخيزههاى آنها در ارتباط با دستاوردهاى ورزش ملى مورد توجه مصرفكنند گان خود قرار كيرد (ع (Y). تحقيق حاضر مؤلفه تصوير و نقش اجتماعى را به عنوان ضعيفترين مؤلفه باور كه بر

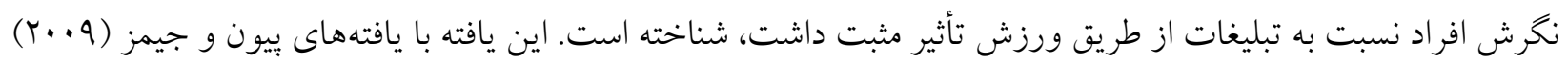
همخوانى دارد. اين موضوع بيانگر آن است كه تبليغات از طريق ورزش در مورد مد روز جامعه به آنها اطلاعات كافى نمى دهد و به خوبى نمىتواند تصوير خوب از جامعه در بين مشتريان بوجود آيد(T0). از سوى ديخر مؤلفهاى منفى باور شامل رنجش يا آزاردهنده بودن، كذب و نامفهوم بودن و مادى گرايى نيز تأثير منفى بر نكرش افراد نسبت به تبليغات از طريق ورزش تأثير داشتند. از مزاياى تبليغ از طريق ورزش ذهنيت مثبى است كه در مصرف كنند كان ايجاد مى كند و باعث مى شود كه عوامل منفى نتواند تبليغات از طريق ورزش را تحت تأثير قرار دهد. در

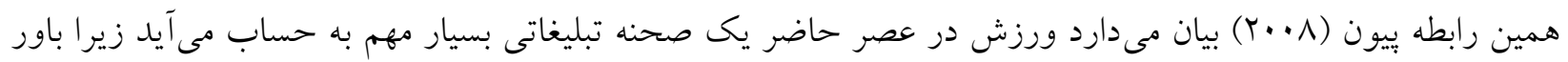
بر اين است كه علاقه و وابستكى افراد به ورزشكاران و تيمهاى ورزشى مىتواند عكس العمل منفى تماشاكران را نسبت به تبليغات از طريق ورزش تغيير دهد(YT). به همين خاطر تبليغ كند كان از طريق ورزش به دنبال ساخت برنامههاى تبليغى مىباشند كه مورد توجه مشتريان قرار كرفته و زمانى كه تبليغات را از طريق ورزش دريافت مىكنند احساس رنجش و آزاردهنده بودن در آنها بوجود نيايد. با توجه به اين موضوع كه تبليغات از طريق ورزش مورد توجه مشتريان قراردارد، 


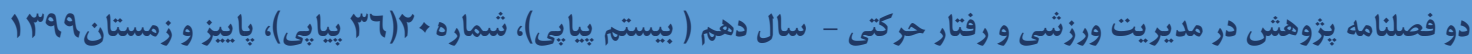

لذا نبايد با تبليغات كذب و نامفهوم زمينه تغيير نخرش را در آنها بوجود آورد. از سوى ديخر تحقيقات نشان مىدهد، تبليغات عمومى باعث بوجود آمدن حس كذب و نامفهوم بودن تبليغات در بين مشتريان شده است. در اين رابطه يرابهاكر و اليوت(r (199) به اين نتيجه رسيدند كه تبليغاتى كه از تلويزيون يخش مى شود باعث رنجش و آزردكى افراد را به دنبال دارد)(YV). يكى از تفاوتهاى بسيار مهم بين تبليغات از طريق ورزش و تبليغات عمومى كه باعث شده تبليغات از طريق ورزش در بين مصرف كنند گان نخرش منفى ايجاد نكند بعد رنجش و آزار دهنده است. اين بعد باور بر تبليغات از طريق ورزش واكنش منفى ايجاد نكرد. لذا مىتوان كفت كه تبليغات از طريق ورزش به دليل علاقه بسيار ورزش دوستان به شخصيتهاى ورزش، جذاب بودن محيط ورزش، احساس خوشايند ايجاد شدن در هنخام ديدن تبليغات بر روى بييراهن بازيكنان و حتى استفاده خود ورزشكاران معروف در زندكى شخصى خود مى تواند منجربه كاهش نخرش آزاردهنده بودن تبليغات از طريق ورزش شود. خوشبختانه ورزش به دليل همه گير شدن در بين اقشار مختلف جامعه و با جايگاهى كه در بين مردم دارد باعث شده تبليغاتى كه از طريق ورزش انجام مىشود مورد يذيرش جامعه قرار بخيرد. يكى ديخر از مؤلفههاى منفى باور در بزوهش حاضر مادى گرايى مىباشد. نتايج يزوهش حاضر نشان داد رابطه

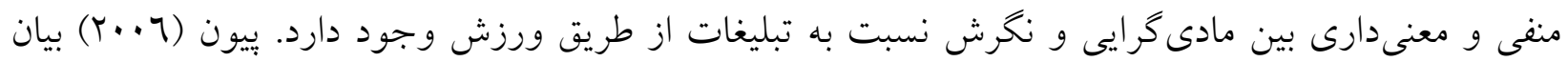
مى دارد كه بين ئزوهشهاى انجام گرفته و مطالعه وى در مورد مؤلفه مادى گرايى توافق وجود دارد و نتايج نشان مىدهد كه درى ياسخ گويان از مؤلفه مادى گرايى تاثير منفى بر نكرش آنها نسبت به تبليغات بر جاى مى گذارد.

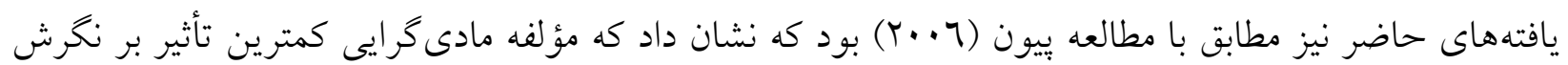
نسبت به تبليغات از طريق ورزش دارد. لذا نبايد از ورزش براى ترويج مادى گرايى استفاده شود يكى از مهمترين ويز گيهاى تبليغات از طريق ورزش بر ساير تبليغات، حس خوشايند بودن بيشترى است كه به مخاطبان القاء مى كند.البته اين موضوع در تبليغات عمومى تا حدودى صادق است، بطورى كه ايز و لى (Y (Y) نشان دادند كه خوشايند و لذتبخش بودن بيشترين تأثير را نسبت به تبليغات دارد(YN). در زمينه ورزش اين موضوع به صورتهاى ديكر خود را نشان داده است مثل استفاده از صحه كذار و شخصيتهاى معروف ورزشى در تبليغات كه بر نخرش افراد نسبت

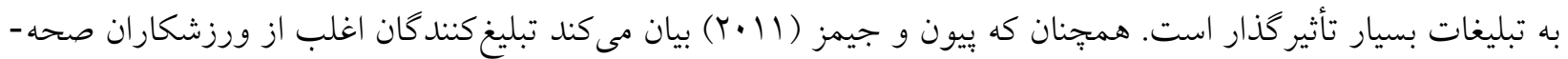

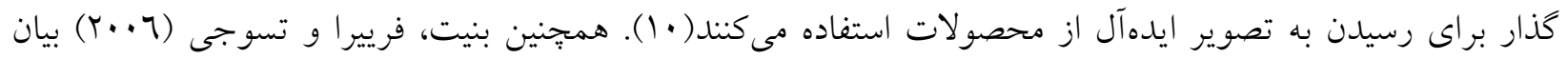
مى دارند كه استفاده از صحه كذاران ورزشكار نقش ارزشمندى در توسعه نام تجارى محصولات دارد. آنها همجنين يادآور مىشوند اكر جهه استفاده از ورزشكاران براى صحه كذارى محصولات و خدمات يك تصميم خوب محسوب مى شود، اما از يكى سو نوعى برنامه يرمخاطره محسوب شده و بايد دقت كافى را در استفاده از صحه كذار در برنامهاى تبليغاتى را داشت(Y9). به نظر مىرسد با توجه به همه گير بودن ورزش به راحتى مىتوان اين روش تبليغاتى را در جامعه رونق داد. 


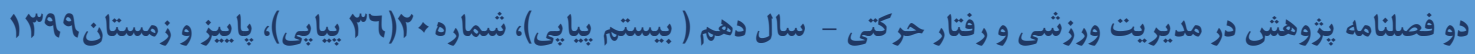

با توجه به اينكه ايران نيز داراى جامعهاى جوان همراه با علاقمندان بىشمار به ورزش و ورزشكاران است، لذا شركتها و سازمانها به راحتى با سرمايه گذارى در اين بخش مى توانند محصولات خود را به جامعه معرفى نمايند. بدين ترتيب تبليغ كنند گان مى توانند براى افزايش اعتماد مشتريان، قبل و بعد از خريد، از صحه كذاران استفاده نمايند( •r).

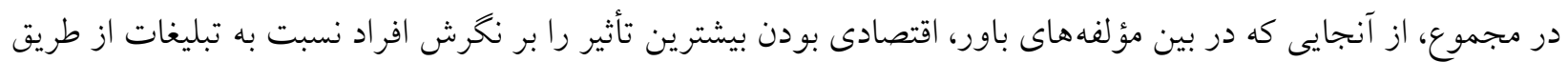
ورزش داشت، بيشنهاد مىشود مواردى همجِون كيفيت محصولات و هزينهاى يرداختى مشتريان متناسب با يكديخر مد نظر قرار گيرد. از طرف ديخر با نحاه اقتصادى به محصولات تبليغى، مشتريان مىتواند انتخابهاى مختلفى را داشته و بر اساس نياز خود مبادرت به تهيه محصولات و خدمات تبليغى نمايند. در تبليغات اين اصل بايد مد نظر قرار كيرد كه مشترى با كيفيت ترين كالا و خدمات را با كمترين هزينه مى خواهد. با توجه به نتايج تحقيق حاضر در مؤلفه اقتصادى بودن، بيشنهاد مىشود فرهنگى در بين بازاريابان و آزانسهاى تبليغاتى بوجود آيد كه در تبليغات تا حد امكان ويز كىهاى اقتصادى محصولات تبليغى مد نظر قرار كرفته تا توانايى تهيه كالاها و محصولات توليدى را داشته باشند. از سوى ديخر با توجه به مؤلفه لذتبخش بودن، تبليغات را طورى طراحى نمايند

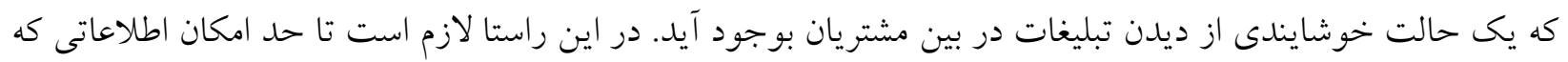

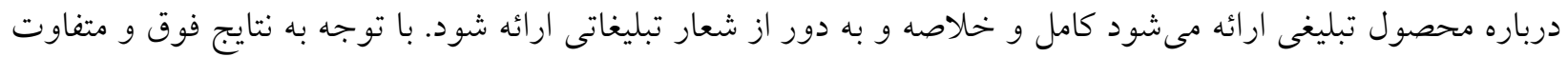

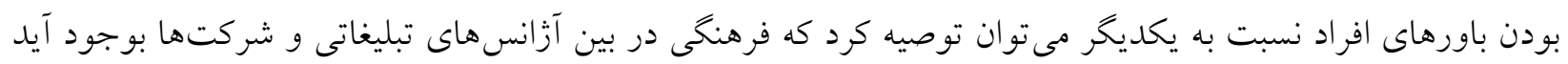
كه مشتريان را در مركز توجه قرار دهد. بدين معنا كه به صورت دورهاى و منظم باورها و نخرشهاى مشتريان مورد

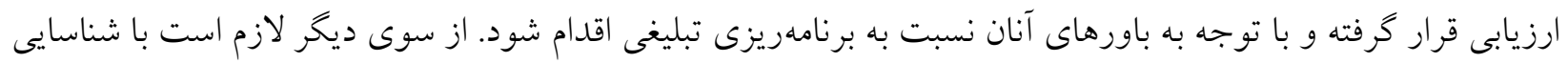

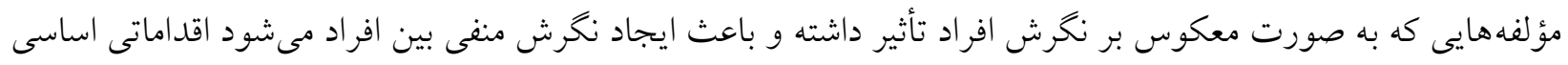
در جهت رفع آنها انجام شود. تمامى تغييراتى كه در تبليغات انجام مىشود بايد بر اساس دادههاى حاصل از ارزيابى باورهاى افراد كه منجر به شكل گيرى نخرش مشتريان به تبليغات مىشود صورت گيرد.

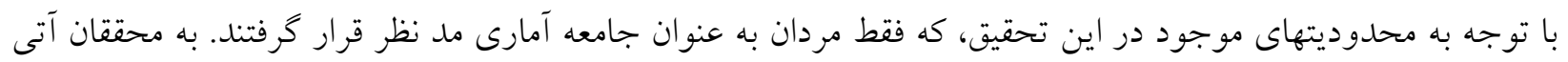
توصيه مىشود كه يزوهشى مشابه بر روى زنان انجام دهند. زيرا ممكن است زنان تفاوتهايى در باورها و نخرش خود نسبت به تبليغات از طريق ورزش داشته باشند. همجنين مقايسهاى بين نخرش بيندانان تلويزيونى (غيرمستقيم) و تماشاگران حاضر در استاديوم (مستقيم) صورت يذيرد تا تفاوت بين نخرش افراد مشخص شود. ازسوى ديخر با توجه به اين كه تبليغات از طريق ورزش شامل جندين نوع از تبليغات را شامل مىشود (تبليغات داخل استاديوم، روى بيراهن بازيكنان، صحه گذارى و...) بيشنهاد مى شود يزوهشگران ديخر نخرش افراد را به صورت جداكانه درباره هر يكى از انواع

$$
\text { تبليغات از طريق ورزش مورد بررسى قرار دهند. }
$$

در مجموع به مديران باشخاهها توصيه مى شود هنخام تبليغ كالاها و محصولات، به جذاب بودن محصولات توجه نمايند زيرا باعث ترغيب هواداران تيم براى خريد محصولات تبليغى از سوى تيم مورد علاقه مىشود. بازاريابان و شركتهاى 


$$
\begin{aligned}
& \text { تبليغاتى نيز بايد از تبليغاتى استفاده نمايند كه علىرغم تازگى محصولات اطلاعات كامل و جامعى درباره محصولات } \\
& \text { تبليغى به مشتريان انتقال داده و مشتريان با مقايسه محصولات بتوانند بهترين كالا را براى رفع نياز خود تهيه نمايند. } \\
& \text { منابع: }
\end{aligned}
$$

1. Khodadad HH, Roosta A, Khalili SV. Advertising (Theoretical and practice approach). Tehran. Negah danesh; 2018. (in Persian).

2. Nikzad F, Ardakani S, Tabatabaei NM. Analytical comparison of Technology Acceptance Model and theory of reasoned action about mobile advertising acceptance. Journal of New Marketing Research. 2014; 3(4): 181-196.

3. Sjjadi SN, Omidi AR, Zare GH. the relationship between the use of sports images in advertisement and the consumer's behavior. Harakat. 2008; 34(34): 83-93.

4. Burns K S. Attitude toward the Online Advertising Format: a Reexamination of the Attitude toward the Model in an Online Advertising Context, the Florida State University; 2003. 180p.

5. Fathi H. Sport and Advertising. Tehran. Amir Kabir. 2018. (in persain).

6. Eagly $\mathrm{AH}$, Chaiken S. Attitude structure and function. In D. T. Gilbert, S. T. Fiske \& G. Lindzey (Eds.), the handbook of social psychology .New York: McGraw-Hill. 1998.

7. Atkinson RC, Atkinson RL, Smith EE, Bem DJ, Nolen-Hoeksema S. Atkinson \& Hilgard's Introduction to Psychology. Tehran. Roshd. 2018. (in Persian).

8. Fazio $\mathrm{RH}$. Attitudes as object-evaluation associations of varying strength, Social Cognition. 2007;25(5): 603-37.

9. Fishbein M. A consideration of beliefs, and their role in attitude measurement. In M. Fishbein (Ed.), Readings in attitude theory and measurement. New York: John Wiley \& Sons, Inc. 1967. $470 p$.

10. Keshmiri N, Elahi A R, Akbari Y H. Effectiveness of Through Sport Advertisement of MTN Irancell in Iran's Professional Football League Based on the AIDA Model. Sport Management Studies, 2017; 9(43): 39-60. (in Persian).

11. Pyun DY, James JD. A proposed relationship between beliefs about and attitude toward advertising through sport, International Journal of Sport Management. 2010; 11(4): 609-627.

12. Bauer RA. Greyser SA. Advertising in America: The consumer view, Boston: Harvard University Press. 1968. 250p.

13. Pyun DY.The Proposed Model of Attitude toward Advertising through Sport, the Florida State University. 2006. 280p.

14. Chittithaworn Ch, Islam Md A, Thooksoon O. Belief Dimensions and Viewer's Attitude towards TV Advertising in Thailand, International Journal of Marketing Studies. 2011; 3(1): 95-102.

15. Muratovic A, Bjelica D, Popovic S. Examining belifs and Attitudes toward Advertising through sport among Montenegrin consumers. Physical Education and Sport, 2014; 21(2):95-104.

16. Shekari A, Mousavi N, Gholami A. Designing the Attitude toward Advertising Model through Mobile Social Networks, Journal of System Management, 2020: 1; 79-98.

17. Pyun DY, kwon HH, Chon TJ, Han JW. How does advertising through sport work? Evidence from college students in Singapore, European Sport Management Quarterly. 2012; 12(1): 43-63.

18. Popovic S, Beliefs about the Influence on Attitudes of Turkish University Students toward Advertising through Sport, Sport Mont 17 (2019) 2: 9-15. 
19. Molnar S, Masanovic B, Bjelica D. Attitudes of Consumers from University of Novi Sad toward Advertising through Sport among the Frequency of Watching Sports Events, J. Anthr. Sport Phys. Educ. 2 (2018) 3: 9-14

20. Behnam M, Tousi T. An Analysis of Relationship between Arousal, Pleasure, Attitude toward Advertisements, Consumers' Future Intention in Sport Service (University of Tehrans' students case study). Applied Research of Sport Managemen. 2014; 2(3): 47-60.

21. Kordloo H. Belief`s and Attitude of Irannian Football Premier Leaque`s Spectators toward Advertising through Sport. University of Kharazmi; 2012. 171p. (in Persian).

22. Kwan PY, Eze UC. The influence of quality, marketing and knowledge capabilities on business competitiveness. International Journal on Innovation and Learning. 2012; 11(3): 288-307.

23. Wang Y,Sun Sh, Lei, W, Toncar M. Examining beliefs and attitudes toward online advertising among Chinese consumers, Direct Marketing: an International Journal. 2009; 3(1): 52-66.

24. Masanovic, B. Attitudes of consumers from Autonomous Province of Vojvodina toward advertising through sport in relation with the frequency of watching sports events. Sport Mont. 2018; 16(3): 91-96.

25. Pyun DY, James JD. Enhancing advertising communications: Developing a model of beliefs about advertising through sport, International Journal of Sport Communication. 2009; 2: 1-20.

26. Pyun DY, James JD, Kwon R. A reexamination of the factor structure of beliefs about advertising through sport: A Singapoore case, In Proceedings of the 6th Annual Conference of the Sport marketing Association, Australia. 2008.

27. Alwitt LF, Prabhaker PR. Functional and beliefs dimensions of attitudes to television advertising: Implications for copytesting, Journal of Advertising Research. 1992; 32(5): 30-42.

28. Eze UC, Lee $\mathrm{CH}$. Consumers' Attitude towards Advertising. International Journal of Business and Management. 2012; 7(13): 94-108.

29. Bennett G, Ferreira M, Tsuji Y. Analyzing the effects of advertising type and antecedent on attitude towards advertising in sport, International Journal of Sport Marketing\& Sponsorship. 2006; 8(1):56- 75.

30. Van heerden N, Kuiper A, Saar MH. Investigating sport celebrity endorsement and sport event sponsorship as promotional cues, South African Journal for Research in Sport, Physical Education and Recreation. 2008; 30(2): 147-165. 